\title{
24. Three New Species of Permian Trilobites from West Japan*)
}

\author{
By Teiichi Kobayashi, M. J. A., and Takashi Hamada \\ University of Tokyo \\ (Communicated March 12, 1980)
}

Trilobites are seldom found in Permian strata of Southwest Japan, although they are not so rare in Northeast Japan. Nakazawa (1958), Imamura (1966) and Akagi (1971) have reported their occurrences from Kyoto, Kochi and Hiroshima Prefectures respectively, but no adequate study has been carried out on them. Here the authors describe three new species with fresh materials as follows:

1. Paraphillipsia levigata, sp. nov. from the Shimoyama limestone, Sakawa basin, Kochi Prefecture, Shikoku Island.

2. Neogriffithides imbricatus, sp. nov. from the Middle Permian limestone, Mt. Ryozen, Shiga Prefecture, Honshu.

3. Pseudophillipsia intermedia, sp. nov. from the Middle Permian limestone (Parafusulina-Neoschwagerina zone) of Neo, Gifu Prefecture, Honshu.

The Shimoyama limestone was first considered Lower (?) Permian, later the Yabeina zone or Upper Permian, but the find of the trilobite suggests Middle Permian for its age, because Paraphillipsia was extensively distributed from Crimea to the Far East through the Himalayas and Southeast Asia in the Permian Period, most flourishing in the Middle Permian age.

Neogriffithides gemmellaroi Toumansky and N. pulchellus (Gemmellaro) are two Middle Permian Socio species, but the latter's variety, alpina Gortani is contained in the Lower Permian. N. imbricatus, together with Paragriffithides levigata, shows the migration of the genera between Japan and Sicily through the Himalayas and Crimea in the Middle Permian Period.

The third species has the cranidium resembling Pseudophillipsia (Carniphillipsia) in the subgeneric range from Westphalian to Lower Permian, but the associate pygidium agrees with the subgenus $P$. (Pseudophillipsia) in the segmentation. Because P. intermedia occurs in the Middle Permian, it must have been derived from any Lower Permian species of $P$. (Pseudophillipsia). This subgenus was also distributed widely from the Mediterranean to the Far East through Caucasus during the Permian Period.

*) Studies of Japanese Trilobites and Associated Fossils-XIX. 
Paraphillipsia levigata, sp. nov.

Figs. 1, a-b, 2, and 3, a-c

Glabella broader in anterior than posterior, suddenly drooping and overhanging frontal margin; medium sized basal lobe limited by obtusely bent linear preoccipital furrow; neck ring strongly expanding in median part, but there occipital furrow is somewhat arcuate with backward convexity ; fixed cheeks narrowing forward from fairly large eyes, opposed at glabellar contraction; free cheek divided by lateral marginal furrow into inner roll and outer border of subequal breadth.

Pygidium broad, well inflated; axial lobe wider than a third of pygidium, breviconic, truncated at terminus, composed of 9-10 rings; pleural lobe gradually arching down laterally, divided into 7-8 flattopped ribs by narrow furrows which die out at half way or two-thirds the lobe; marginal rim narrow and depressed.

This species is diagnostic of Paraphillipsia. It is closely allied to $P$. karpinskyi Toumansky, though this glabella is less expanded in anterior, preoccipital lobe shorter, eyes somewhat larger and the pygidium having one or two more segments. Another close ally is $P$. inflata Kobayashi and Hamada from Thailand, but the glabella is more parallel-sided in that species.

Neogriffithides imbricatus, sp. nov.

Fig's. 4, a-c

Pygidium subtrigonal and strongly inflated; axial lobe strongly arched up, longiconic, composed of 18 or more rings, strongly descending near posterior terminus where the lobe is overhanging and truncated; axial rings protruded upward and backward in median part in form of imbrication in lateral view; pleural lobe composed of 12 ribs beside the first narrow rib; short interpleural furrow inserted from lateral side in a few anterior ribs; marginal border narrow and ridged. Test smooth.

Neogriffthides gemmellaroi Toumansky has a similar subtrigonal pygidium whose axial lobe has an arching crest like this species. Ring furrows and pleural and interpleural furrows are, however, very strong and test is tuberculate in that species. The salient median crests of the axial rings and their imbrication are most distinctive of this species.

\section{Pseudophillipsia intermedia, sp. nov.}

Figs. 5 and 6 , a-c

Cranidium with broad glabella whose main lobe is subquadrate, expanding forward; its frontal margin broadly arcuate; lateral furrows absent; occipital and preoccipital furrows well pronounced; preoccipital lobe trisected into a broad median part and a pair of diagonal- 
ly elongate basal lobes ; frontal border convex, separated from glabella by deep furrow; fixed cheek very narrow; eyes small, opposed at the mid-length of the cranidium.
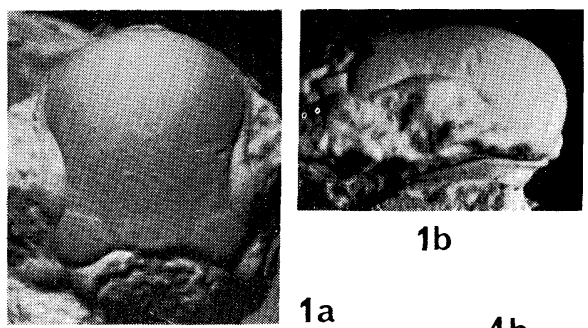

1b

$1 \mathrm{a}$
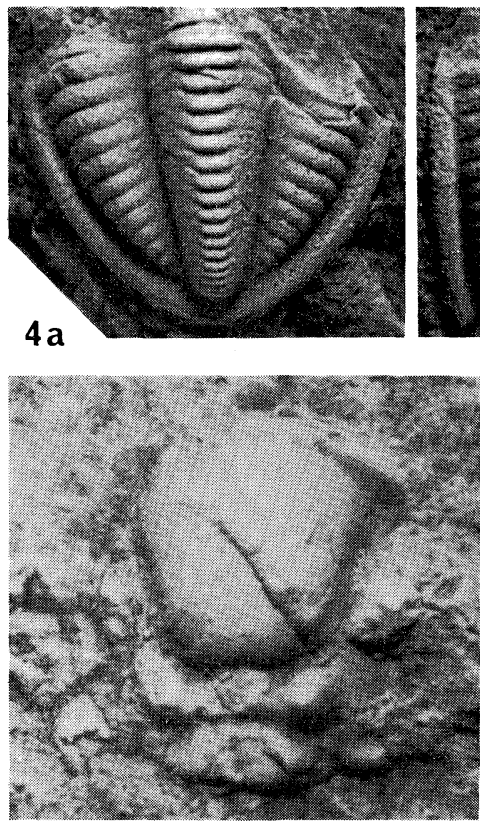

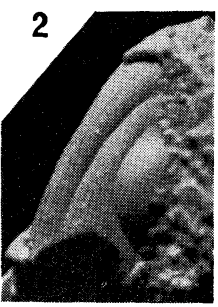

$4 b$

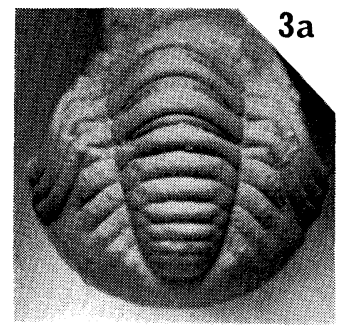

$3 a$

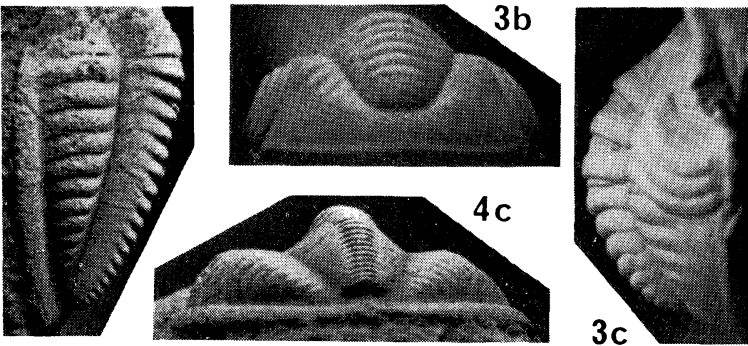

$6 \mathbf{a}$

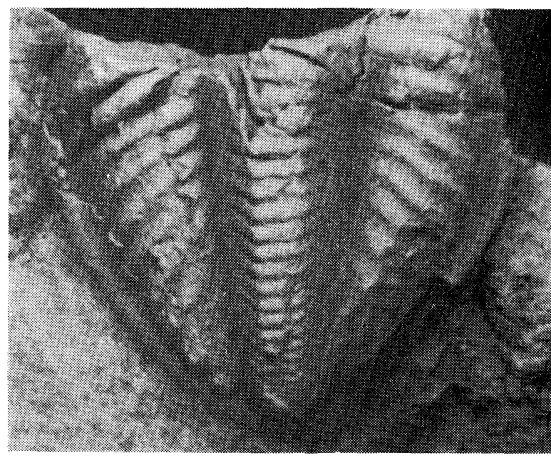

$6 c$
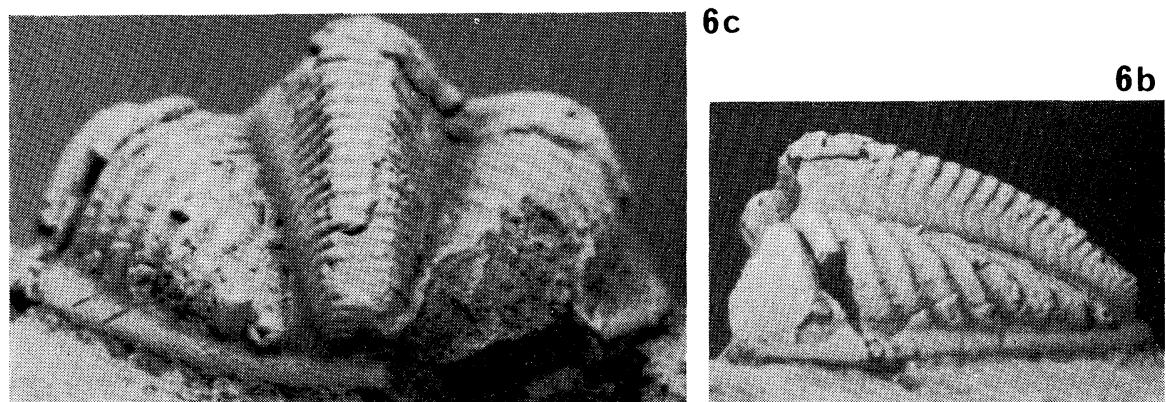

Figs. 1-6. 1-3: Paraphillipsia levigata, sp. nov. 1, a-b: Holotype, $\times 3.3$. 2: $\times 2.6$. 3a: $\times 3.4$. 3,b-c: $\times 4.7$. 4: Neogriffithides imbricatus, sp. nov. 4, a-c: Holotype, $\times 4.7$. 5-6: Pseudophillipsia intermedia, sp. nov. 5: Holotype, $\times 6.9 .6, \mathrm{a}-\mathrm{b}: \times 3 . \quad 6 \mathrm{c}: \times 4.8$. 
Pygidium parabolic, widest at a quarter of length behind articulating margin; axial lobe a third as wide as pygidium, composed of 25 rings, truncated at rear end where a median slit cuts into the lobe and an axial ridge is seen on bottom; pleural lobe divided into 13 simple ribs by profound furrows; marginal furrow deep; marginal border narrow and convex.

In the lack of lateral furrows this cranidium agrees with Pseudophillipsia (Carniphillipsia) Hahn and Brauckmann, 1975, closely resembling P. (C.) ogivalis javornikensis Hahn and Ramovš, 1977, although the main glabellar lobe is smaller and eyes are much larger and located more posteriorly in that species. The associate pygidium of this species, on the contrary, disagrees with the subgenus in the multisegmentation, namely Carniphillipsia has 17-21 axial rings and 9-13 pleural ribs, while Pseudophillipsia s. str. has 20-27 axial rings, 13-17 pleural ribs.

The known range of the subgenus, Carniphillipsia, is from Westphalian to Lower Permian with acmic prominence in Stephanian or Gshelian. The present species was obtained from the Middle Permian Parafusulina-Neoschwagerina zone. Therefore it is probably a derivative from any older species of $P$. (Pseudophillipsia) by effacement of the lateral glabellar lobes.

The present authors express their thanks to Messrs. T. Imamura, J. Inoue, and T. Ono who collected the described specimens and offered them to us for study.

\section{References}

Akagi, S. (1971): Lower Permian arthropods from the Taishaku limestone, Southwest Japan. J. Fac. Sci. Tottori Univ., Nat. Sci., 22, 79-86, pl. 1.

Gemmellaro, F. G. (1882): I crostacei del calcari con Fusulina della valle del Flume Socio nella provincia di Palermo i Sicilia. Mem. mat. fis. Soc. Ital. Sci., 4, ser. 8 (1), 1-40, 5 pls.

Gortani, M. (1906) : Contribuzioni allo studio del Paleozoico Carnico, 1. La fauna permocarbonifera del Col Mezzodi presso forni Avoltri. Palaeontogr. Ital., 12, 1-84, pls. 1-3.

Hahn, G., and Brauckmann, C. (1975) : Revision zweier Trilobiten-Arten aus dem Perm Asiens. Geol. Paleont., 9, 117-124.

Hahn, G., and Ramovš, A. (1977) : Trilobiten aus dem Ober-Karbon (Gshelium) der Karawaken/Slowenien. Geol. Paleont., 11, 135-160, 2 pls.

Imamura, T. (1966): Discovery of a trilobite from the Shimoyama limestone (Permian). J. Geol. Soc. Japan, 72, 451-452.

Kobayashi, T., and Hamada, T. (1979): Permo-Carboniferous trilobites from Thailand and Malaysia. Geol. Pal. SE Asia, 20, 1-21, pls. 1-3.

Nakazawa, K. (1958) : A new fossil locality of Permian trilobite. Chikyu Kagaku, no. $36,27$.

Toumansky, O. (1935): The Permo-Carboniferous Beds of the Crimea, Part 2. The Permo-Carboniferous Trilobites of Crimea. pp. 1-63, pls.1-12. 
Yabe, H., and Sugiyama, T. (1934): Amblysiphonella and Rhabdactina gen. and sp. nov. found from Upper Palaeozoic limestone of Mimikire near Sakawa-machi, Tosa Province, Shikoku. Japan. J. Geol. Geogr., 11 (3/4), 175-180, pls. 20-22. 